\title{
A Classical Case of Duchenne Muscular Dystrophy
}

\section{Sohail $\mathbf{A}$ and Imtiaz $\mathbf{F}^{*}$}

Department of Biochemistry, Dow Medical College, Dow University of Health Sciences, Pakistan

*Corresponding author: Fauzia Imtiaz, Department of Biochemistry, Dow Medical College, Dow University of Health Sciences, Pakistan, Tel: 021-99215754; E-mail: f.imtiaz@duhs.edu.pk

Rec date: November 1, 2014, Acc date: January 3, 2015, Pub date: January 6, 2015

Copyright: $\odot 2015$ Sohail A, et al. This is an open-access article distributed under the terms of the Creative Commons Attribution License, which permits unrestricted use, distribution, and reproduction in any medium, provided the original author and source are credited.

\begin{abstract}
An 8 year old boy was presented for difficulty in walking and muscle weakness with difficulty in climbing stairs, running and particularly in vigorous physical activities, he also had decreased strength and endurance. His parents did not have consanguineous marriage, one brother and two sisters were all healthy; no other family members were similarly affected.
\end{abstract}

Keywords: Myopathy; Muscular dystrophy; Calf muscles

\section{Case Report}

An 8 year old boy was presented for difficulty in walking and muscle weakness with difficulty in climbing stairs, running and particularly in vigorous physical activities, he also had decreased strength and endurance. His parents did not have consanguineous marriage, one brother and two sisters were all healthy; no other family members were similarly affected.

On examination, he had difficulty jumping onto the examination table, a Gower sign (a sequence of maneuvers for rising from the floor (Figure 1), proximal weakness of pectoral and pelvic girdle muscles, a waddling gait tight hell cords, and apparently enlarged calf muscles (Figure 2).

His serum creatine kinase and aldolase levels were 50 fold higher than normal (Table 1), motor nerve conduction studies revealed low amplitude compound muscle action potentials throughout, with normal conduction velocities. The history, physical examination findings and elevated creatine kinase/aldolase levels strongly suggested a case for myopathy. Serum aldolase test indicates muscle degeneration and a definite aid in distinguishing primary myopathy from secondary or neurogenic muscle atrophy [1]. The family was counseled, therefore, the risk for carrier daughters was 33\% and his brother would be $0 \%$ as the mutation is thought to be arising at the time of conception of the boy in this case.

\begin{tabular}{|l|l|l|}
\hline Demography & & Levels of enzymes \\
\hline Age & 8 yrs & \\
\hline Sex & Male & \\
\hline CK & & $7476 \mathrm{U} / \mathrm{L}(\mathrm{NV}=150$ to $499 \mathrm{U} / \mathrm{L})$ \\
\hline Aldolase & & $23.94 \mathrm{U} / \mathrm{L}(1$ to $7.6 \mathrm{U} / \mathrm{L})$ \\
\hline
\end{tabular}

Table 1: Levels of CK and Aldolase.

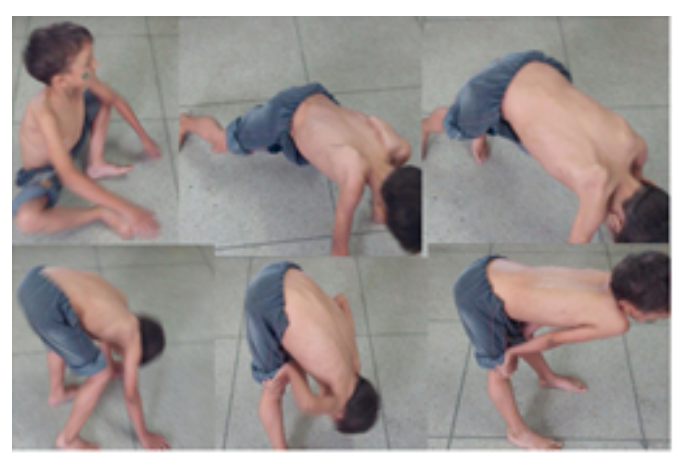

Figure 1: Patient with DMD use Gower s maneuver sign

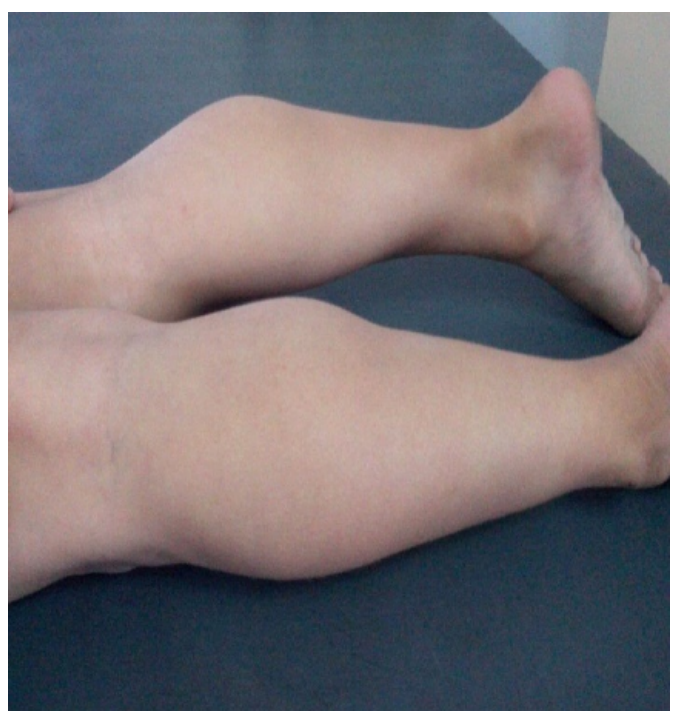

Figure 2: Patient with DMD enlarged calf muscles 
Page 2 of 2

$\mathrm{DMD}$ is an $\mathrm{X}$-linked recessive progressive myopathy, with an incidence of about 1 in 3500 male live births [2] was first described by French neurologist Guillaume Benjamin Amand Duchenne in 1860s.

DMD is described as progressive myopathy leading to muscle weakness and eventually its degradation. Muscle weakness progresses from hip girdle muscles and neck flexors, the shoulder girdle and distal limb and trunk muscles. Usually boys are affected at the age of 3 to 5 years, present due to difficulty in climbing stairs or rising from sitting position, most patients using Gowers maneuvers, and enlarged calf muscles are present classically, due to replacement of muscles by fats by the age of 12 years. Patients can survive beyond 20 years of age in areas with advanced medicine but usually die due to respiratory failure or cardiac failure as about $95 \%$ patients with DMD develop cardiac abnormalities or both [2] in absence of advanced support. Serum creatine kinase levels are grossly elevated above normal limit. DMD patient have on average IQ approximately 1 standard deviation below the mean.

\section{Discussion}

Dystrophin is a structural protein in skeletal muscle, cardiac muscle and brain. It interacts with multimeric protein complex associated with sarcolemma proteins which plays an important role to maintain integrity of muscle membrane [2].

Molecular genetic studies indicate that dystrophin is a huge gene located on the short ( $\mathrm{p}$ ) arm of the $\mathrm{X}$ chromosome at position 21.2.and about two thirds of mutations in this gene lead to DMD but no clear correlation found between the extent of deletion and severity of disorder. The protein product of the human and mouse DMD loci by using polyclonal antibodies directed against fusion proteins reflecting 2 distinct regions of the mouse cDNA. The protein, called dystrophin, is about $400 \mathrm{kD}$ in size and represents about $0.002 \%$ of total striated muscle protein [3].

The finding of dystrophin mRNA in brain may explain mental retardation in DMD patients [4]. Dystrophin in brain is transcribed from a different promoter from that used in muscle. The brain-type promoter of the dystrophin gene is highly specific to neurons. By contrast, the muscle-type promoter is active in a wider range of cell types, including not only striated and smooth muscle, but also glial cells to a lesser extent, and probably neurons [5].

The replacement of the missing protein, dystrophin, using myoblast transfer in humans or viral/liposomal delivery in the mouse DMD model is insufficient and short-lived. An alternative approach to treatment would be to upregulate the closely related protein, utrophin, which might be able to compensate for the dystrophin deficiency in all relevant muscles [6].

\section{Acknowledgement}

Mr. Ateeq Ur Rehman, Institute of Physical Medicine and Rehabilitation (IPM\&R)

\section{References}

1. Richard A, Thompson MD, Paul JV Jr, Cleveland MD (1959) Serum aldolase in muscle disease. AMA Arch Intern Med. 103 (4): 551-564.

2. Nussbaum R, McInnes RR, Willard HF (2007) Thompson \& Thompson genetics in medicine. Elsevier Health Sciences.

3. Hoffman EP, Brown RH Jr, Kunkel LM (1987) Dystrophin: The protein product of the Duchenne muscular dystrophy locus. Cell 51: 919-928.

4. Chamberlain JS, Pearlman JA, Muzny DM, Gibbs RA, Ranier JE, et al. (1988) Expression of the murine duchenne muscular dystrophy gene in muscle and brain. Science 239: 1416-1418.

5. Chelly J, Kaplan JC, Maire P, Gautron S, Kahn A (1988) Transcription of the dystrophin gene in human muscle and non-muscle tissues. Nature 333: 858-860.

6. Tinsley JM, Potter AC, Phelps SR, Fisher R, Trickett JI, et al. (1996) Amelioration of the dystrophic phenotype of $\mathrm{mdx}$ mice using a truncated utrophin transgene. Nature 384: 349-353. 